\title{
Reaching the Meaning of Life: a Case Study of Sawitri dan Tujuh Pohon Kehidupan the Novel
}

\author{
Dyah Prabaningrum ${ }^{1}$, Rahayu Pristiwati ${ }^{2}$, Sumartini $^{3}$ \\ \{1dyahprabaningrum@mail.unnes.ac.id, ${ }^{2}$ pristi@mail.unnes.ac.id, ${ }^{3}$ sumartini@mail.unnes.ac.id\} \\ 1,2,3 Indonesian Language and Literature Department, Languages and Arts Faculty, Universitas Negeri \\ Semarang
}

\begin{abstract}
Life probematics has psychological consequences for humans. Humans are vulnerable to face stress because of their demands both from themselves and the environment, so that sometimes it makes them choose the wrong attitude. Expectation provides an opportunity to grow and develop positively for the meaningfulness of life. The desire to live meaningfully leads people to a life which full of meaningful activities so that humans become valuable and meaningful individuals. A meaningful life is termed in psychology with logotherapy. In accordance with this statement, literature can provide a definition related to a meaningful life and the efforts of the characters in it to reach a meaningful life. Therefore, this study examines the efforts of characters in achieving the meaning of life in Sawitri dan Tujuh Pohon Kehidupan the novel that was examined by using a psychology approach to literary. This research is a qualitative description research. The method in analyzing data is the hermeutics method. The results of the study are the actualization of creative value, experience value, expectation value, and the value of behaving on the characters in the novel to achieve meaningful of life.
\end{abstract}

Keywords: character efforts, meaning of life, logoterapi, and psychological of literature.

\section{Introduction}

Life probematics has psychological consequences for humans. In determining their attitude, humans can become proactive agents that build hope when facing problems. Nevertheless, humans are susceptible to feel stress because of demands from both themselves and the environment so that it makes them choose the wrong attitude. Kompas.com [1] stated that the level of stress of Indonesian people is below the average level of stress of global society. However, it is only $25 \%$ of Indonesian people who are free from stress. It means that as many as $75 \%$ people are susceptible to stress. It is closely related to the hopes of the Indonesian people. As many as 44 percent of Indonesian people hope that they will be taken care of by their children when they are old. This number is higher than the expectation of the global community which only 22 percent who wants to be treated by children when they are old. Shane Lopez [2] explained that hope can help us in the moment of stress and anxiety. Hope provides an opportunity to grow and develop positively for the meaningfulness of life. 
The desire to live meaningfully leads humans to a life that full of meaningful activities, so that humans become valuable and meaningful individuals [3]. Psychology expert, Victor Frankl named life meaningfulness as logotherapy. Frankl [4] stated that the meaning of life can be found in four values, namely: creative value, experience value, attitude value, and expectation value. Creative value is obtained through creation and work. Through creation and work humans can find meaning in life and understanding the life meaningfully. However, the work is only a media that provides opportunities to discover and develop the meaning of life. Thus, the meaning of life does not mean in work but rather depends on attitudes and work methods that reflect personal commitment to the work. Second, the value of experience is understanding and believing in a value (truth, goodness, beauty, justice, faith, love, etc.) that can make a person have a meaning in life. Three, the value of behaving. Through accepting sincerely and steadfastly about this unpleasant experience, it is expected that the mental burden can be reduced. In fact, it might be able to provide valuable experience and wisdom so it can creates life meaningful. This suffering can help the process of maturity and contribute the positive value in the future. Thus, it shows that suffering/ unpleasant life experiences can give meaning if the individual is able to overcome well. Finally, the value of hope is the belief that something good will happen or a good change will occur in the future. Although expectation does not always come true, but it can provide opportunities and solutions as well as new goals that can lead to enthusiasm and optimism. In accordance with this, Soleha's research [5] described that logotherapy gives the goodness for the owner. Logotherapy increases the ability to reflect and make a person refrain from their inappropriate behavior.

Literature as social documentation illustrates the complexity of life through problems telling and character. Therefore, revealing and describing the results of the structure analysis of the novel is a strategy for indirect learning. Besides, there are literary works (novels) that tell the characters' efforts to live in varies life. Thorough the background of Javanese culture in the rural environment of the novel Sawitri dan Tujuh Pohon Kehidupan illustrates the complexity of married life, hopes, and life values that are carried out to accept destiny so that life is not poor of depression or stress [6]. The lack of research on the meaningfulness of life, especially in literary works will be the value of this research. Nevertheless, there are several studies that are relevant to the author's research. The research conducted by Vos and Diago Vitali [7] published in Journal of Palliative \& Supportive Care Volume 16, issue 5, on pages 608-632. The study entitled "The Effects of Psychological Meaning-Centered Therapies on Quality of Life and Psychological Stress: a Metaanalysis." The study illustrates that meaning centered therapies provide a positive influence on life and reduce stress. Then, second, Wulandari's research [8] was published in the proceedings of the 2018 National Guidance and Counseling Seminar at PGRI University in Madiun entitled "Menumbuhkan Nilai Budi Pekerti Masyarakat Jawa Mawas Diri dengan Logo Terapi". Wulandari argued that logotherapy is positively related to the growth of character values and introspective.

\section{Research Method}

This research is a qualitative description research. The approach in this research is the psychological of literature. The method in data analysis is the hermeutics method. The consequence of using hermeneutics as a method is tied to two things, especially ensuring the contents in a word, sentence, text, and so on. Second, understand the forms of instruction contained in symbolic symbols [9]. In analysing this literary work, the writer devides the 
elements in the work, especially the characters and the characterization of the work which is a reflection of the author's way to plant and develop the values of life in Sawitri the novel. This is intended so that researchers can examine the efforts of leaders in achieving the meaning of life in Sawitri dan Tujuh Pohon Kehidupan the novel through the study of psychological of literature.

\section{Results And Discussion}

Every person will actualize to achieve a meaningful life. One of the characters in Sawitri dan Tujuh Pohon Kehidupan the novel is Sukaisih. Sukaisih did meaningful activities in order to achieve the meaningful life. Sukaisih who has not yet been blessed with children from her marriage has the idea to open an orphanage. It can be seen at the following quote

"Beberapa pekan berikutnya, kami pun mulai mengurus administrasi dan persyaratan untuk membuka sebuah rumah social, semacam panti asuh kecilkecilan, mengingat rumah kami lumayan lebar dan hanya dihuni dua orang serta seorang pembantu yang datang di pagi hari dan pulang di sore hari.” (hlm. 173) [10]

In this situation, Sukaisih actualizes herself to the social environment, in accordance with human characteristics that have achieved the meaning of life according to Maslow's formula [11]. This is done by Sukaisih so that her life can be useful for others that can make her life meaningful. Sundari also said the same in the following quotation. This points out by the creative value appears from Sukaisih activity namely build an orphanage.

Behind the self-actualization conducted by Sukaisih, there is also the ability of Sukaisih to accept conditions that could have occurred. Able to accept themselves, others and the natural world as it is in accordance with the characteristics of individuals who have achieved the meaning of life according to Maslow [12]. Seen in the following quote.

"Namun, upaya puncak dari seorang manusia hanya sebuah upaya terbaik dan segenggam doa, dan aku sudah melakukan itu untuk sepuluh bocahku. Kalaupun nasib membawa mereka ke cerita lain, itu suratan utuh yang mereka bawa semenjak lahir." (hlm. 174)

In other hand, Syajari strives to attain meaningfulness of life by taking on the meanings of every event in his life, both pleasant and unpleasant. As in the following quote.

"Yah, setidaknya aku terus berusaha untuk mengisi masa tuaku ini dengan mengingat banyak kebahagiaan dan hal-hal baik. Kalaupun nanti aku harus pergi meninggalkan orang-orang tercinta, aku tak mau pergi dalam keadaan rapuh dan terpuruk.". (hlm.43)

Syajari felt happiness in his life and wanted to welcome the next life with happiness too. The key is acceptance of human nature. The form of acceptance for the realization of life means not only to the destiny given by God, but also to the unpleasant experiences. Acceptance of an unpleasant experience is seen in Syajari's figure as follows.

“... Aku Cuma berusaha memberi pemahaman kepada diri sendiri, terus-menerus, supaya tidak menyesal apalagi mengeluh, sekecil apa pun itu, sadar atau tidak 
sadar. Kalau tidak banyak-banyak merenung dan memperbarui semangat hidup, tentu kita sudah gila dari dulu. Ya, tho?" (hlm.211)

In this situation, Sawitri reprimanded her husband for not daydreaming too much. Then Syajari answered that he was not daydreaming but pondering about his life. In this case Syajari learned to accept all the experiences in his life, especially the unpleasant experiences that befell some of his children. Even to the unpleasant things that happen to him too. It can be said that in his old age, Syajari tried to make his life meaningful, both from pleasant and unpleasant experiences throughout his life. This is what Frankl refers to as attitude value. The attitude of acceptance from Syajari was also apparent when remembering Sumitrah's way of life.

“....kejadian yang menyebabkan Sumitrah jadi pendiam seumur hidup itu tak pernah kami harapkan. Kejadian semacam itu tak pernah diharapkan oleh orangtua mana pun. Maka, ketika kemudian kami sadar bahwa kami hanya manusia lumrah, kejadian itu pun kami anggap sebagai sebuah kausa..." (hlm.209)

From Syajari's remembrance of Sumitrah's life journey, we can find out the stages of attaining meaning in life according to Anggriyani [13]. The first stage is the stage of suffering, where Syajari is devastated by events that befall Sumitrah by saying that such incidents were not any parent has ever hoped for. Syajari was able to go through the stage of suffering then enter this stage of acceptance when he realized that he was just a normal human. After realizing this, Syajari discovered the meaning of the incident, which was that he also needed friends at home after the death of his other children. The discovery of meaning led to the realization of meaning, namely Syajari and Sawitri remain grateful for the current condition of Sumitrah.

The stages to achieve the meaning of life also seem analogous to the life of the tree, as shown in the following quote.

"Api telah mengunyah daun-daun kami dan siap menyatukannya dengan tanah, muasal dari kami. Kami telah terbiasa menyaksikan itu semua. Dan karenanya kami belajar, bahwa wadah yang cukup untuk setiap kejadian di muka bumi ini adalah sabar dan syukur." (hlm.118)

In that situation, leaves are compared to children. The tree, the mother, suffers when she sees the leaves falling and burning. However, because this is the destiny that accompanies it every day, the tree learns to accept that destiny and can take on meaning. The meaning of the incident is to be patient and grateful.

The value of being very influential individuals in the discovery of the meaning of life. Individuals can find meaningful life when they can interpret unpleasant events positively. Conversely, if more individuals interpret negative events negatively, they will feel that their lives have no meaning. In the novel Sawitri and Tujuh Pohon K Birth, the value of a positive attitude that encourages the discovery of the meaning of life is shown by Syajari in the following quote.

"seperti apa pun kisah bocah-bocah itu, aku tak berhak membenci mereka, aku tetap merasa bangga kepada mereka, kalaupun beberapa dari mereka tak bisa melangkah dengan baik, setidaknya mereka tidak melangkah di jalan yang salah." (hlm.46) 
Syajari is remembering her children one by one. Not all children live easy and good lives. Nevertheless, Syajari did not regret and remained grateful to have them. Also visible at the time Syajari specifically thinking about the condition of Sumitrah.

"Apa yang menimpa Sumitrah tak ada kaitannya dengan pohon itu, yang dialami Sumitrah hanyalah nasib buruk yang memang harus ditanggungnya. Itu cobaan bagi Sumitrah, bagi kita, dan kita tak bias berbuat banyak." (hlm.53)

The quote is a conversation between Syajari and Sawitri, his wife. At that time, Sawitri wanted to cut Sumitrah's Flamboyan tree because she felt she could not bear the burden of sadness over the mental condition that befell Sumitrah. Sawitri cannot accept the condition. But Syajari taught acceptance that the condition of Sumitrah had nothing to do with trees. Syajari's positive attitude is also evident from the narrative of Sawitri in the following passage.

"Namun, sepanjang ingatanku, lelaki itu tak pernah mengeluh. Ia berbeda, ia dilahirkan untuk menghadapi kecemasan-kecemasan. Ia selalu punya cara untuk mengubah keluhan-keluhan menjadi ruang yang selalu cukup untuk menanam harapan. Ia memiliki sihir dalam perkataan dan tingkah lakunya. Dari caranya memperlakukan pohon, kami sudah tahu bagaimana cara lelaki itu memperlakukan kehidupan, dan kami merasa sangat beruntung memilikinya di tengah-tengah kami." (hlm.45)

Said Sawitri explained that in the hands of Syajari, complaints can turn into gratitude. Though humans are born with the feeling of being easily worried. But Syajari was able to deal with this anxiety by being grateful for all the events that happened, both pleasant and unpleasant. Thus, Syajari can be said to have the value of being positive towards an unpleasant experience.

Unlike Syajari and Sawitri, some of their children have a negative attitude. Especially Sumitrah and Subandi. Sumitrah experienced an event that made her devastated and suffered. But he was immersed in the suffering and failed to take the positive side of the incident. As shown in the following quote.

“Aku tak peduli lagi pada dunia luar, hanya saja, ketika terdengar suara berisik di luar, aku akan mengintip, mungkin saja orang-orang itu ada di pihakku dan bias mengusir orang-orang berpakaian hitam itu. Namun tidak, orang-orang berpakaian hitam itu seperti hantu dan bias menjelma apa saja. Bahkan menjelma orang-orang yang wajahnya kukenali. Bisa saja itu mereka. Mereka hantu. Atau mungkin iblis. Dan mereka bias melakukan apa saja." (hlm.136)

Sumitrah cannot accept the full of unpleasant experiences that occur in her life. This makes him always shadowed by fear and regret that reject the outside world. Sumitrah cannot take the positive side and then feels that life is meaningless.

The same thing happened to Subandi although in the end what happened to Subandi was not as heavy as Sumitrah. Subandi is shadowed by feelings of guilt and regret. Look at the following quote.

"Lihatlah, Subandi, apa yang harus kaualami untuk menebus rasa malumu terhadap keluarga sendiri? Aku terlentang menatap langit-langit yang pekat, segalanya hitam, wajah Bapak dan Ibu tiba-tiba membayang, menjelma cahaya yang membuat bibirku tersenyum. Bapak? Ibu? Bagaimana kabar kalian? Apakah 
kalian akan bahagia jika aku pulang? Atau kalian akan cemas karena aku selalu merusak hari-hari kalian? Bapak... Ibu..." (hlm.250)

In that situation, it was described that Subandi had never returned home since leaving. The reason is Subandi's shame over his bad behavior when he was a child and his youth. His family is often troubled by it. Subandi regretted and the quote was his anxiety towards his family and the burden of regret that he bore. However, the fruit of that regret encouraged him not to go home because of shame. Subandi cannot take the value of being positive so that he even ignores his longing and family feelings. The hope of becoming a father is also seen in the following quote.

"Sawitri lebih suka memanggilku 'Pak', menurutnya, dengan begitu, ia telah menyiapkan ruang yang berisi harapan-harapan bahwa aku akan menjadi bapak." (hlm.40-41)

In that situation, Sawitri indirectly implanted Syajari that he was a father, father of their children. This makes them remain optimistic through life. Nevertheless, the hope must still be accompanied by efforts so that these expectations are achieved. Even so with Syajari who hopes that his life is useful by becoming a father. Look at the following quote.

"Sawitri tersenyum. Dan pada detik itu, aku baru menyadari kata-kataku, bahwa mungkin kami memang harus berdoa lebih banyak lagi, juga berbuat baik lebih banyak lagi. Bersama dengan itu pula, mendadak aku memikirkan sebuah janji kepada diri sendiri, janji yang tiba-tiba muncul di batok kepalaku. Kelak, jika kami memiliki anak, ketika istriku melahirkan anak pertama, aku akan menanam sebatang pohon yang kuperuntukkan bagi kelahirannya. Dan pohon itu akan kunamai dengan namanya." (hlm.41)

Syajari was determined to do good, besides hoping and praying. Syajari wants to be not only beneficial for fellow humans but also for plants and nature. This he intends along with the birth of their children one by one.

Having hopes of making people feel optimistic was also apparent when Sunardi wanted to continue his studies abroad on a scholarship. Sunardi asked his parents for permission and so was the answer given by Sawitri.

"bahkan kalau itu ke ujung dunia, kau harus tetap pergi. Kata adikmu benar, tak semua orang bisa mendapat kesempatan sepertimu, dan pengalaman itu mahal. Belajar di negeri orang akan membuatmu banyak belajar hal-hal baru. Jadi kau harus pergi." (hlm.177)

Sawitri had the hope that studying abroad would broaden her horizons and knowledge. Sawitri is optimistic that this will bring Sunardi to success. Therefore he did not hesitate to allow Sunardi to study abroad. But not necessarily the reality that happens in life in accordance with expectations. The fact that is not as expected gives rise to regret. As told by the following.

"Aku berharap uang hasil kerja keras yang kukirimkan setiap bulan itu bisa membantu Bapak dan Ibu menyekolahkan adik-adikku sampai jenjang tertinggi. Namun, akhir-akhir ini baru kusadari, bahwa berkecukupan saja tidaklah cukup. Berbahagialah yang membuat segalanya menjadi cukup." (hlm. 126) 
In that situation, Sumaiyah tried to work hard in other countries so that she could help her family so they could feel happy. However, the reality that occurs is not entirely consistent. Sumaiyah can indeed help in material terms, but she sacrificed togetherness with her family so that she still did not get happiness.

When reality does not meet expectations, humans need to have full acceptance of the conditions experienced in order to continue to be able to achieve a meaningful life. In the novel Sawitri and Tujuh Pohon Hidup the attitude of acceptance of whatever possibilities that occur in life is shown by Syajari below.

"Anak-anak adalah milik diri mereka sendiri. Anak-anak punya ciri khas seperti barang titipan, dan tentu kau cukup mafhum seperti apa sifat dari barang titipan itu. Ya. Suatu saat kau harus melepaskannya. Mengembalikannya kepada yang punya. Ketika kau menyadari bahwa kepergiaan anak-anak adalah keharusan yang tak perlu kautangisi, kau baru akan bisa merasakan ketenangan hidup di masa senjamu." (hlm.209)

In that situation Syajari realized that he had certain expectations for his children, including the hope to remain accompanied. However, the children remain private and Syajari accepts it fully if one day their children go far from him. This awareness leads to inner calm and that's when the meaningfulness of life can be felt.

If we observe, in fact it is rarely occur that a research which discusses logotherapy (meaningfulness of life) that is related to literary works. However, there are several journals or articles that discuss the issue of meaningfulness in life. First, an article entitled "The Effects of Psychological Meaning-Centered Therapies on Quality of Life and Psychological Stress: a Metaanalysis". This article was published by one of journals in United Kingdom. The article illustrated that meaning centered therapy has a positive influence on life and reduce stress. Second, an article entitled " Logoterapi ve Din" [14]. This article was published by one of journals in Turkey. In the article, it was explained that logotherapy was used to solve psychological disorder especially stress. In addition, in the article explained the relationship between logotherapy and religion. There are similarities in the scriptures and logotherapy theory, Frankl believes that humans can manage their own guilt. He also believes that humans can choose to be better in their future. This is also found in the scriptures. Lastly, Logotherapy is also discussed in the article entitled [15]"A Rekreatif Aktivitelere Psikolojik Açi dan Yaklaşim: Viktor Frankl Ekolününİncelenmesi". In the article that was published by one of journals in Turkey explained that there are findings, Frankl explained recreational activities as a mechanism/ activity/ phenomenon: (1) Feeling control mechanism of existential inequality (2) Activity of fulfill the finding of individual meanings (3) The recreational activity is directed to meaningful feeling (4) Phenomena related to the intention of recreation to make life meaningful. These articles have provided an understanding related to the implementation of Frank's theory. However, a variety of examples need to implement Frank's theory. As a simulation of understanding the reality, Frank's theory of the meaning of life can be presented in the novel. We wrote this article, to provide diversity and examples of application to Frank's Theory so that readers can live a meaningful life [16]. 


\section{Conclusion}

The character's efforts to achieve the meaning of life in the novel Sawitri dan Tujuh Pohon Kehidupan are illustrated in their characteristics to live life. The pursuit of the meaning of life can be found in four values, namely: creative value, experience value, attitude value, and expectation value. Creative values at the same time possessed by Sukaisih who founded an orphanage before being blessed with a baby. He actualizes himself to the social environment, not dissolve in sadness. A similar value also underlies the attitude of another character, Sundari. Sundari's creative value is apparent from her teaching children to learn. Experience values are metaphorically illustrated by trees. Trees provide an explanation for the leaves that will fall. The depiction is an analogy for human life, especially the relationship between parents and children. Besides that, it is also illustrated by Syajari's attitude that strives to attain meaningfulness of life by taking on the meanings of every event in his life, both pleasant and unpleasant. Likewise the attitude of hope, Syajari and Sawitri feel happiness in their lives and want to welcome the next life with happiness too. The key to happiness and meaningfulness of life is acceptance of human nature.

\section{References}

[1]. Kompas.com. Secara Global, Tingkat Stres Orang Indonesia Disebut Paling Rendah [Internet]. Kompas.com. $2018 . \quad$ Available from: https://lifestyle.kompas.com/read/2018/07/09/193000820/secara-global-tingkat-stres-orangindonesia-disebut-paling-rendah?page $=$ all

[2]. Lopez S. Lima Hal yang Membuat Kita Harus Terus Memupuk Harapan. [Internet]. BBC.com. 2019. Available from: https://www.bbc.com/indonesia/indonesia-46733383.

[3]. Frankl V. Meraih Hidup Bermakna : Kisah Pribadi dengan Pengalaman Tragis. Jak: Paramadina; 1996.

[4]. Frankl V. Logoterapi : Psikologi untuk Menemukan Makna Hidup dan Meraih Hidup Bermakna. Jakarta: Rajawali Press; 2007.

[5]. Soleha. Makna Hidup Bagi Pengikut Ajaran Tarekat Qadiriyah Wa Naqsyabandiyah (Tqn) Di Sukamara Kalimantan Tengah. J Teol. 2015;26(2)(2):323-46.

[6]. Prabaningrum D. Penanaman dan Pengembangan Nilai-Nilai Kehidupan sebagai Strategi Pendidikan Karakter melalui Analisis Novel Sawitri dan Tujuh Pohon Kehidupan: Kajian Psikologi Sastra. Semarang; 2019.

[7]. Vos J, Vitali D. The Effects of Psychological Meaning-Centered Therapies on Quality of Life and Psychological Stress: a Metaanalysis. J Palliat Support Care. 2018;16(5):608-32.

[8]. Wulandari DA. Menumbuhkan Nilai Budi Pekerti Masyarakat Jawa Mawas Diri dengan Logo Terapi. In: Prosiding Seminar Nasional Bimbingan dan Konseling 2018 Universitas PGRI Madiun. Universitas PGRI Madiun; 2018. p. 155-61.

[9]. Bleicher J. Hermeneutika Kontemporer: Hermeneutika sebagai Metode, Filsafat, dan Kritik. Yogyakarta: Fajar Baru; 2003.

[10]. Zainal M. Sawitri dan Tujuh Pohon Kelahiran. Jakarta: Alvabet; 2018.

[11]. Adnan J, Kiswanto. Determinant of Auditor Ability to Detect Fraud with Professional Sceptisism as A Mediator Variable. Account Anal J. 2017;6(3):313-25.

[12]. Schultz. D. Psikologi Pertumbuhan, Model-model Kepribadian Sehat. In Yogyakarta: Penerbit Kanisius; 1991.

[13]. Pranungsari D, Tentama F. Kebermaknaan Hidup Anak Jalanan Perempuan yang Memiliki Anak Atas Kehamilan yang Tidak Dikehendaki. Humanit J Psikol Indones. 2018;15(1):24-34.

[14]. Arif YILDIZ. Logoterapi ve Din. R\&S-Research Stud Anatolia J [Internet]. 2018;1(2):389-93. Available from: www.dergipark.gov.tr/rs 
[15]. Approach P, Recreational TO. Rekreatif Aktivitelere Psikolojik Açidan Yaklașim : 2019;(3):118.

[16] K. Saddhono, "Language and superdiversity: Indonesians knowledging at home and abroad. By Zane Goebel." Soc. Stu. vol. 12 no.1 pp. 113-118, 2018 